\title{
Article \\ Alkali-Treated Titanium Coated with a Polyurethane, Magnesium and Hydroxyapatite Composite for Bone Tissue Engineering
}

\author{
Mahmoud Agour ${ }^{1,+}$, Abdalla Abdal-hay 2,3,*,+(D), Mohamed K. Hassan 1,4 ${ }^{\text {, Michal Bartnikowski }}{ }^{2}$ \\ and Sašo Ivanovski $2, *$ (D) \\ 1 Department of Production Engineering and Design, Faculty of Engineering, Minia University, \\ Minia 61112, Egypt; agour.mahmoud@gmail.com (M.A.); mkibrahiem@uqu.edu.sa (M.K.H.) \\ 2 Centre for Orofacial Regeneration, Reconstruction and Rehabilitation (COR3), School of Dentistry, \\ Herston Campus, The University of Queensland, 288 Herston Road, Herston, QLD 4006, Australia; \\ michal.bartnikowski@uq.edu.au \\ 3 Department of Engineering Materials and Mechanical Design, Faculty of Engineering, \\ South Valley University, Qena 83523, Egypt \\ 4 Department of Mechanical Engineering, College of Engineering, Umm Al-Qura University (UQU), \\ Mecca 24381, Saudi Arabia \\ * Correspondence: abdalla.ali@uq.edu.au (A.A.-h.); s.ivanovski@uq.edu.au (S.I.) \\ + Those authors contributed equally to this work.
}

check for updates

Citation: Agour, M.; Abdal-hay, A.; Hassan, M.K.; Bartnikowski, M.;

Ivanovski, S. Alkali-Treated Titanium

Coated with a Polyurethane,

Magnesium and Hydroxyapatite

Composite for Bone Tissue

Engineering. Nanomaterials 2021, 11,

1129. https://doi.org/10.3390/

nano11051129

Academic Editor: Ilaria Armentano

Received: 25 March 2021

Accepted: 20 April 2021

Published: 27 April 2021

Publisher's Note: MDPI stays neutral with regard to jurisdictional claims in published maps and institutional affiliations.

\begin{abstract}
The aim of this study was to form a functional layer on the surface of titanium (Ti) implants to enhance their bioactivity. Layers of polyurethane (PU), containing hydroxyapatite (HAp) nanoparticles (NPs) and magnesium $(\mathrm{Mg})$ particles, were deposited on alkali-treated Ti surfaces using a cost-effective dip-coating approach. The coatings were assessed in terms of morphology, chemical composition, adhesion strength, interfacial bonding, and thermal properties. Additionally, cell response to the variably coated Ti substrates was investigated using MC3T3-E1 osteoblast-like cells, including assessment of cell adhesion, cell proliferation, and osteogenic activity through an alkaline phosphatase (ALP) assay. The results showed that the incorporation of HAp NPs enhanced the interfacial bonding between the coating and the alkali-treated Ti surface. Furthermore, the presence of $\mathrm{Mg}$ and HAp particles enhanced the surface charge properties as well as cell attachment, proliferation, and differentiation. Our results suggest that the deposition of a bioactive composite layer containing $\mathrm{Mg}$ and HAp particles on $\mathrm{Ti}$ implants may have the potential to induce bone formation.
\end{abstract}

Keywords: magnesium and its alloys; hydroxyapatite; surface modifications; titanium implants; corrosion analysis; biocompatibility; bioactivity

\section{Introduction}

Titanium (Ti) and its alloys are extensively used in orthopedic implants due to their favorable corrosion resistance, biocompatibility, machinability, and load bearing capability [1-3]. However, because of the bioinert nature of titanium, the osseointegration of Ti implants is relatively slow and can be compromised in sites of limited bone quality and quantity. Various methods of surface modification of Ti implants using physical, chemical, and biochemical treatment methods have been previously established $[1,2,4,5]$, with the aim to enhance osseointegration of the $\mathrm{Ti}$ implants and promote their local bioactivity. Previous studies have shown that good surface wettability enhances the attachment, proliferation, and differentiation of osteoblasts and their precursors, leading to enhanced bone healing [4,6-11]. Additionally, surface chemistry plays an important role in the early stages of bone formation, with the greatest benefits derived from osteoconductive materials, such as hydroxyapatite HAp $\left(\mathrm{Ca}_{10}\left(\mathrm{PO}_{4}\right)_{6}(\mathrm{OH})_{2}\right)$. HAp has been widely used for bone tissue engineering due to its excellent biocompatibility, bioactivity (chemical bonding ability 
with natural bone), slow in situ biodegradability, high osteoconductivity, osteoinductive potential, non-toxicity, and immunomodulatory properties [12,13]. However, HAp coatings are often problematic due to the low bonding strength of pure HAp coatings and Ti substrates $[1,10,14-21]$. The difference in the thermal expansion coefficients of Ti and HAp can cause delamination of the coating, leading to the failure of implants clinically.

Recently, magnesium $(\mathrm{Mg})$ alloys or $\mathrm{Mg}$ coatings on metallic substrates were introduced in medical applications [1,22,23]. Our recent publication [4] showed that the incorporation of $\mathrm{Mg}$ particles into a biodegradable polymer not only enhanced the surface wettability, but also improved cell attachment and proliferation. We thus speculated that a composite polymer film composed of biodegradable metallic Mg particles and HAp NPs, successfully deposited on alkaline-treated Ti surfaces using a simple and cost-effective dip-coating method, is an efficient method to enhance the surface biocompatibility of Ti implants and subsequently improve osseointegration. The incorporation of HAp NPs within the polymer matrix may be capable of enhancing the interfacial strength between the alkali-treated Ti substrate and the polymer matrix by promoting increased hydrogen bonding and inducing superior adhesion. Previous studies have verified the strong interfacial strength between sodium titanate hydrogel layers formed on alkali-treated Ti and HAp particles [24-26]. In addition, HAp NPs present within the polymer matrix can become entrapped in the microporosity of the alkali-treated Ti surface, thus establishing mechanical interlocking with the Ti substrate. Furthermore, the incorporation of Mg particles in a biodegradable polymer matrix is advantageous as the release of acidic byproducts of polymer degradation can be compensated through the increase in $\mathrm{pH}$ facilitated by the dissolution of $\mathrm{Mg}$ [27-30]. Barrère et al. [31] demonstrated that the existence of $\mathrm{Mg}$ in an apatite (a phase of HAp) [13] coating of a titanium surface strengthened the adherence of the coating through the $\mathrm{Mg}$ ions, promoting further apatite precipitation.

Therefore, the aim of the present study is to incorporate both Mg metal and HAp NPs into a biodegradable polymer matrix and subsequently dip-coat a thin layer of this composite onto Ti substrates to enhance their bioactivity. Herein, polyurethane polymer $(\mathrm{Pu})$ was utilized as a polymer matrix because it has a moderate degradation rate, good biocompatibility and exhibits a natural self-healing property [32]. In the present study, $5 \mathrm{wt} . \%$ synthesized HAp NPs [33] and $10 \mathrm{wt} . \% \mathrm{Mg}$ microparticles [4,12] were incorporated into a PU polymer matrix before deposition through dip-coating onto alkali-treated Ti substrates. The morphological properties, chemical composition, surface roughness, wettability, adhesion strength, interfacial bonding, and thermal properties of the composite coating layer were investigated. Furthermore, MC3T3-E1 osteoblast-like cell adhesion, proliferation, and alkaline phosphatase (ALP) activity was studied in response to coated and uncoated Ti substrates.

\section{Materials and Methods}

The present study used a commercially pure titanium (c.p. Ti) sheet (William Gregor Ltd., London, UK), which was cut in a square shape with dimensions of $12 \times 12 \times 2 \mathrm{~mm}^{3}$. The sample preparation included grinding, polishing, and cleaning, according to previous publications [10,34-38]. Untreated samples were then etched in $\mathrm{H}_{2} \mathrm{SO}_{4}: \mathrm{HCl}: \mathrm{H}_{2} \mathrm{O}=1: 1: 1$ volume ratio at $60^{\circ} \mathrm{C}$ for $1 \mathrm{~h}$ to increase the surface roughness [39]. The hydrophilicity was enhanced by subjecting the etched samples to alkaline treatment using the same procedures as described elsewhere $[35,36,39]$. Briefly, the samples were immersed in $100 \mathrm{~mL}$ of an aqueous solution of $5 \mathrm{M} \mathrm{NaOH}$ at $60^{\circ} \mathrm{C}$ for one day. Before further analysis, the samples were rained three times in distilled water and dried at $50{ }^{\circ} \mathrm{C}$ for $24 \mathrm{~h}$ at atmospheric conditions [10]. A HAp nanopowder was prepared using a wet chemical procedure, as described previously $[4,12,33,40]$. Further details on the preparation process of HAp is shown in the Supporting Information. Scanning electron microscope (SEM) image and $\mathrm{X}$-ray Diffraction (XRD) profiles of the synthesized HAp powder are shown in Figure 1a,b. The average diameter of the HAp particles was $120 \pm 30 \mathrm{~nm}$. 

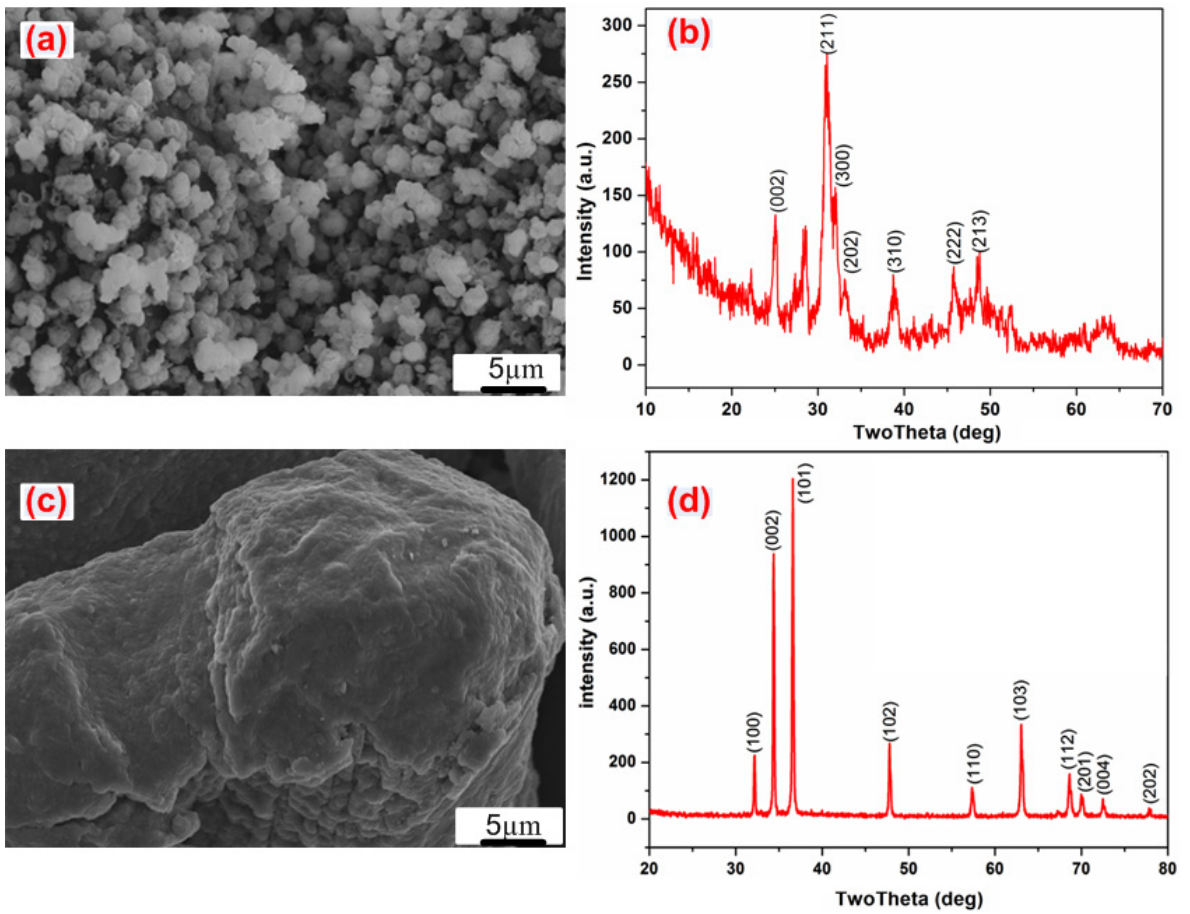

Figure 1. Scanning electron microscopy (SEM) images and X-ray diffraction (XRD) patterns of: (a,b) HAp, (c,d) Mg powders.

Coating process: Polymer solution containing $15 \mathrm{~g}$ of PU pellets (54,600 Da molecular weight, Estane skythane X595A-11, Lubrizol Advanced Material, Inc., Co., Ltd., Seoul, Korea) was dissolved in $100 \mathrm{~mL}$ dimethylformamide (DMF, Loba Chemie PVT. LTD., Mumbai, India). Mg powder with a purity of $99.9 \%$ (Kt, Sigma-Aldrich, St. Louis, MO, USA) and particle size range from 40 to $140 \mu \mathrm{m}$ (SEM morphology and the XRD profile of the as-received $\mathrm{Mg}$ particles are shown in Figure 1c,d) was added into the PU solution at $10 \mathrm{wt} . \%$ (based on the PU weight contribution). Furthermore, 5 wt.\% of HAp NPs, again based on the PU amount, was added into the Mg-particles/PU suspension solution.

Prior to the dip-coating process, all treated and untreated samples were pre-heated over a heating plate at $200^{\circ} \mathrm{C}$ for $10 \mathrm{~min}$ to remove entrapped air and moisture from the surface. After this preheating process, the samples were immersed in the prepared solutions for about $30 \mathrm{~s}$ to facilitate wettability on the surface. Both dipping and withdrawing were performed at the same speed $\left(2.0 \mathrm{~mm} \cdot \mathrm{s}^{-1}\right)$ by a dip-coating machine (EF-5100, E-Flex, Bucheon, Korea), as displayed in Figure 2. The coated sheet was then hung in a vacuum oven (10 mbar) at $40{ }^{\circ} \mathrm{C}$ for $12 \mathrm{~h}$. The drying temperature was selected based on the glass transition temperature of PU [41,42]. Due to the vertical orientation of the hung sample, there was an outflow of solution from the substrate that could affect the thickness of the coating film. However, previous studies have shown that the coating uniformity is improved when the sample is dried in a vertical rather than horizontal orientation [43-45]. Four groups of samples (S0-S3) were prepared and investigated. Table 1 describes the characteristics of the four groups. Characterization and cell culture experiment are shown in the Supporting Information for further details.

Table 1. Designation of sample groups used in this study.

\begin{tabular}{cc}
\hline Sample Designation & Description \\
\hline S0 & Alkaline-treated Ti \\
S1 & Plain PU film coated on alkaline-treated Ti \\
S2 & Mg-particle/PU composite film coated on alkaline-treated Ti \\
S3 & Mg-HAp/PU composite film coated on alkaline-treated Ti \\
\hline
\end{tabular}




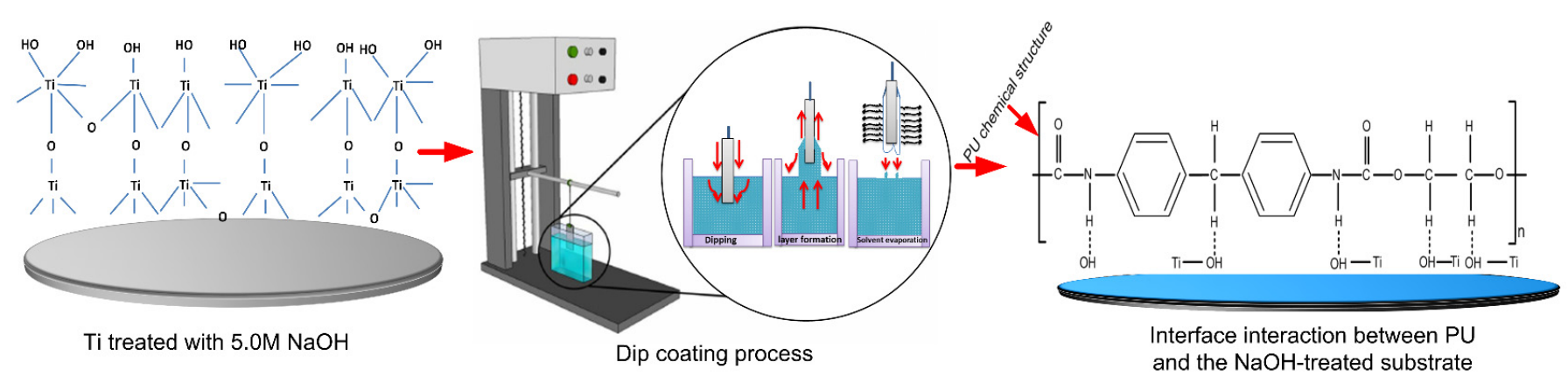

Figure 2. The dip-coating process and the considerable electrostatic intermolecular interaction between the polymer coating and the Ti substrate at the PU polymer side chain. Dotted line indicates electrostatic interaction.

\section{Results and Discussion}

The XRD curves of the surface of Ti treated with $5 \mathrm{M} \mathrm{NaOH}$ solution at $60{ }^{\circ} \mathrm{C}$ for $24 \mathrm{~h}$ are displayed in Figure 3. A small peak with a broad signal on the 2-theta axis at around $24^{\circ}$ was observed. For the S0 group, outstanding peaks due to the $\alpha$-phase of Ti always existed in the diffraction patterns [46]. Broad, small, and low intensity peaks were detected in the XRD profiles around the two- $\theta$ angle of $58^{\circ}$, which was due to the presence of an amorphous sodium titanate hydrogel layer with an atomic ratio similar to the $\mathrm{Na}_{2} \mathrm{TiO}_{3}$ phase formed by $\mathrm{NaOH}$ treatment, as illustrated in previous studies, including ours $[33,46,47]$. This is likely due to the significant chemical reaction that occurred after the $\mathrm{NaOH}$ treatment of the commercially pure Ti surface. However, a previous study [46] did not show the formation of $\mathrm{Na}_{2} \mathrm{TiO}_{3}$ gel layer on the surface of $\mathrm{Ti}$, which is in contrast with the present study. This further verifies the well-optimized parameters for $\mathrm{NaOH}$ treatment of Ti samples in the present work. The morphological properties and high surface area of the $\mathrm{Na}_{2} \mathrm{TiO}_{3}$ formed layer (as shown in Figure 4a) are the reason for the obtaining improvement in adhesion of the subsequent PU polymer coating, which will be discussed later. SEM (Figure 4b) and XRD (Figure 3) observations suggested the presence of a new layer of sodium titanate on the surface of S0, which is likely associated with enhanced adhesion performance of the coated films [10]. Figure 5a,b shows the Mg microparticle and HAp nanoparticle distribution within the PU matrix.

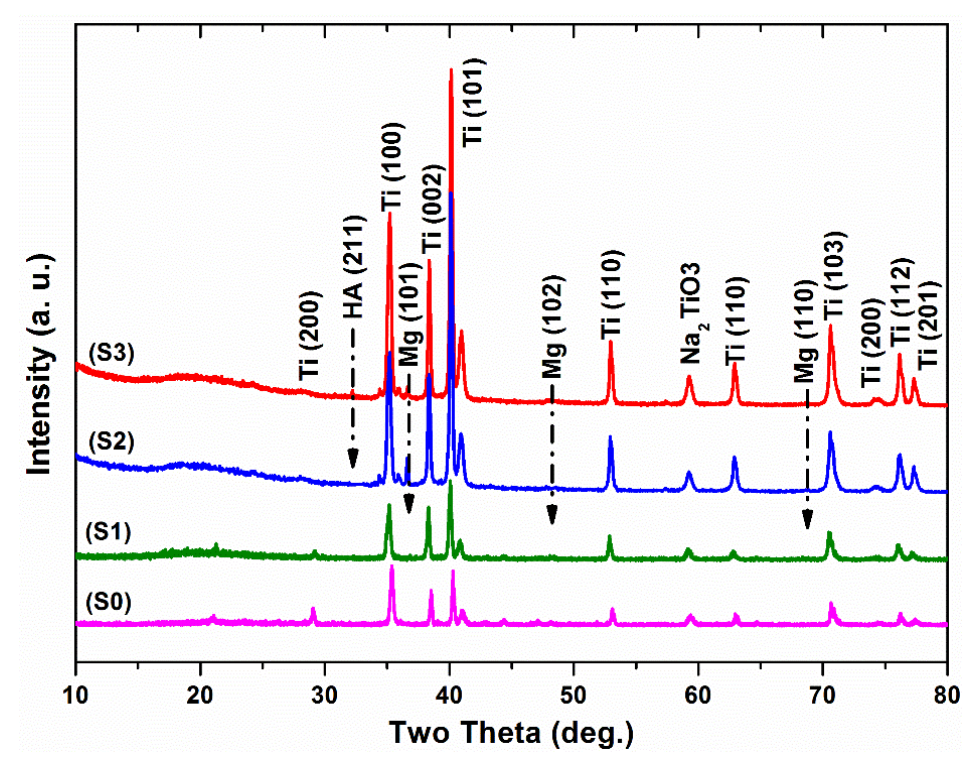

Figure 3. X-ray diffraction profiles of the coated samples. The formation of $\mathrm{Na}_{2} \mathrm{TiO}_{3}$ gel layer at two-theta with an angle of $58^{\circ}$, incorporation of $\mathrm{Mg}$ microparticles and HAp NPs within PU film at 2-theta, $36^{\circ}, 48^{\circ}, 57^{\circ}$ for $\mathrm{Mg}$ particles and $32^{\circ}$ for HAp NPs are illustrated by dashed vertical Dotted marks over the XRD profiles. 

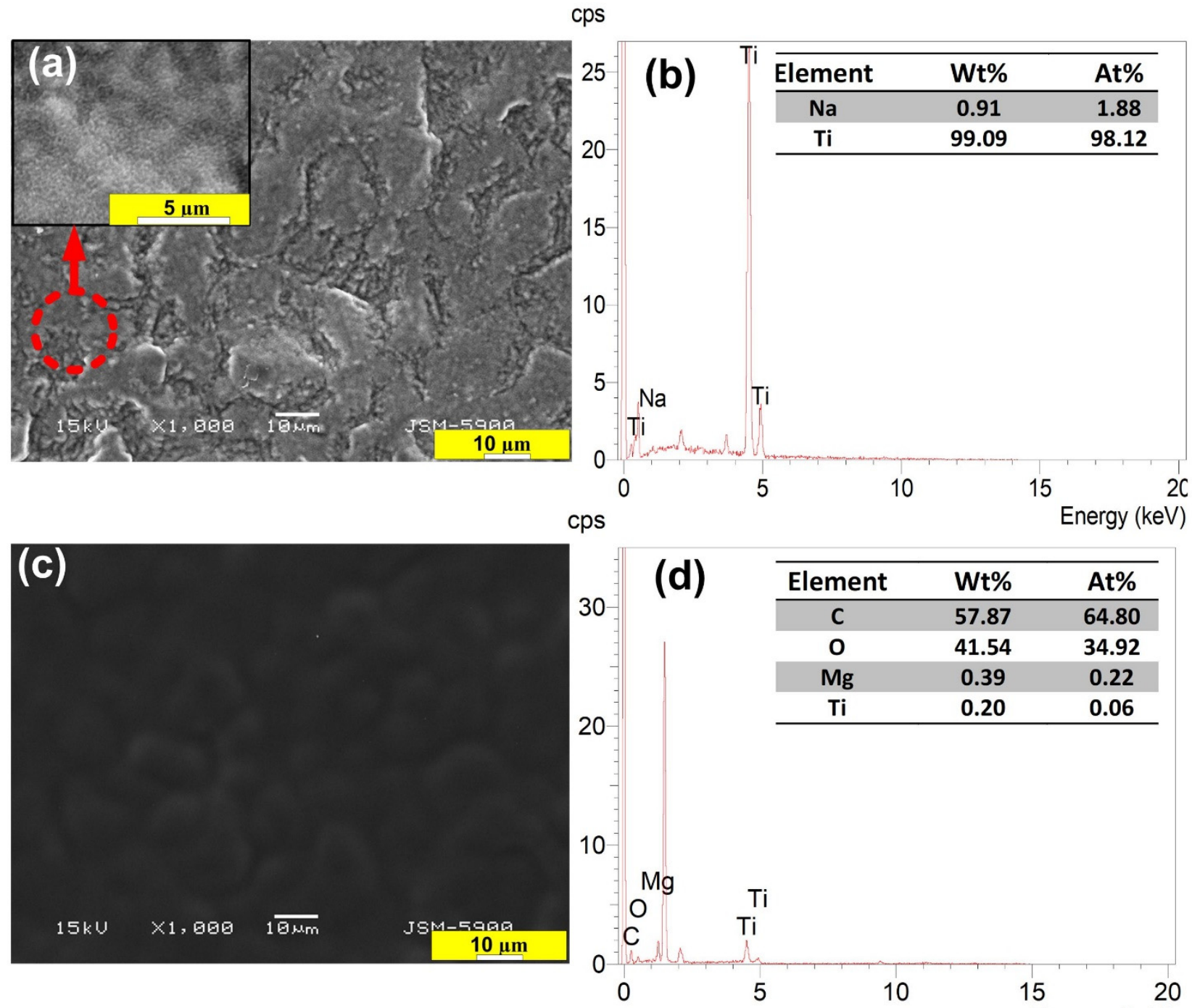

cps

Energy $(\mathrm{keV})$
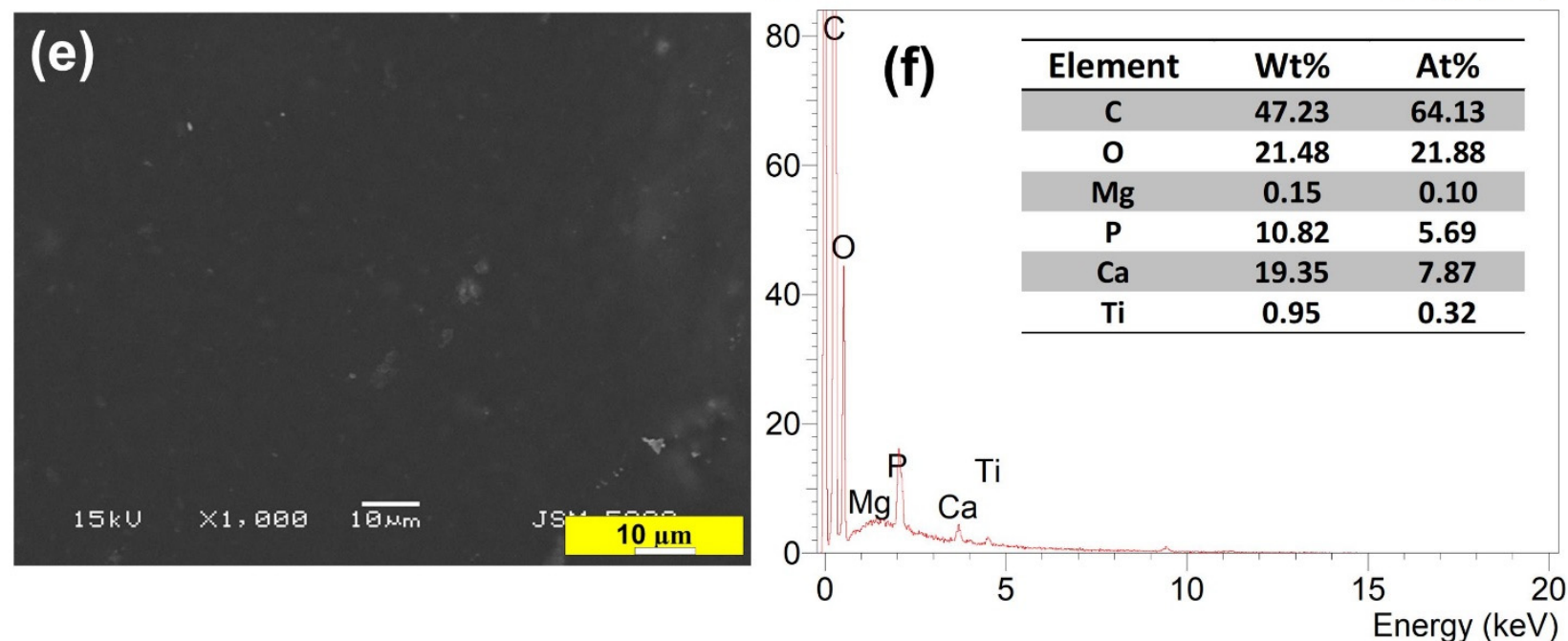

Figure 4. SEM images and their corresponding EDS profiles of S0 (a,b), S2 (c,d), and S3 (e,f) samples. The analysis of the corresponding SEM image are presented as insets of corresponding panel. 

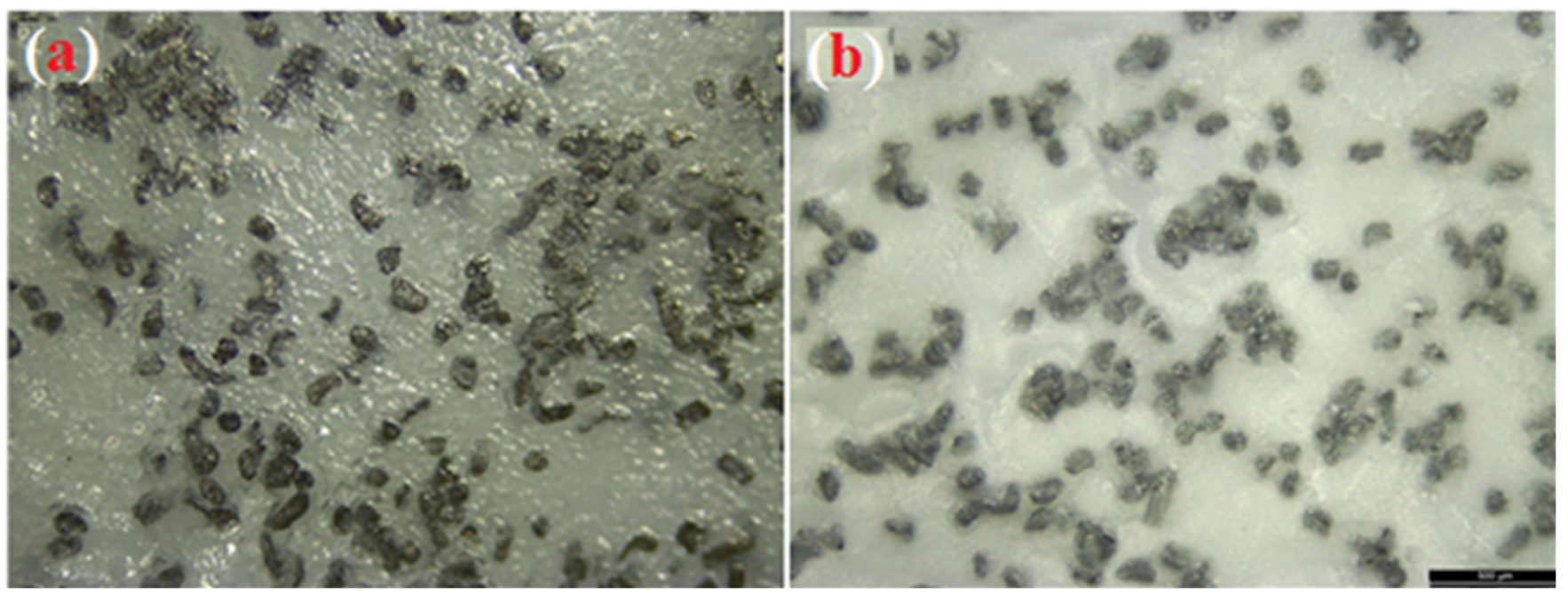

Figure 5. Optical microscopy images showing the distribution of $\mathrm{Mg}$ particles (a) and Mg-particles/HAp (b) throughout the PU layer.

The phase composition of the PU film coated on the untreated and treated Ti surfaces was also investigated using the XRD technique. From the obtained results, it was found that the formation of weak, broad peaks refer to the polymeric phase profile on the Ti surface (see the left-hand side of XRD curves in Figure 3). In addition, the XRD of the composite coated films (S2, S3) showed weak peaks at approximately $34^{\circ}, 36^{\circ}, 48^{\circ}, 57^{\circ}$, indicating the deposition of magnesium particles, and at about $32^{\circ}$, indicating the deposition of HAp particles [30]. SEM images (Figure 4) showed that the S2 group had a smooth and dense morphology, while the S3 group had well-developed upright (columnar) morphological structures, created on the alkaline Ti surface. The surface composition of the coated samples was analyzed by EDS, as depicted in Figure 4d, f. From the EDS analysis, it was confirmed that the $\mathrm{Mg}$ (Figure 4d) and HAp particles (Figure 4f) were successfully doped into the PU polymer coating layers. The thickness of the measured coating layer ranged from 8.14 to $9.74 \mu \mathrm{m}$, as shown in Figure 6.

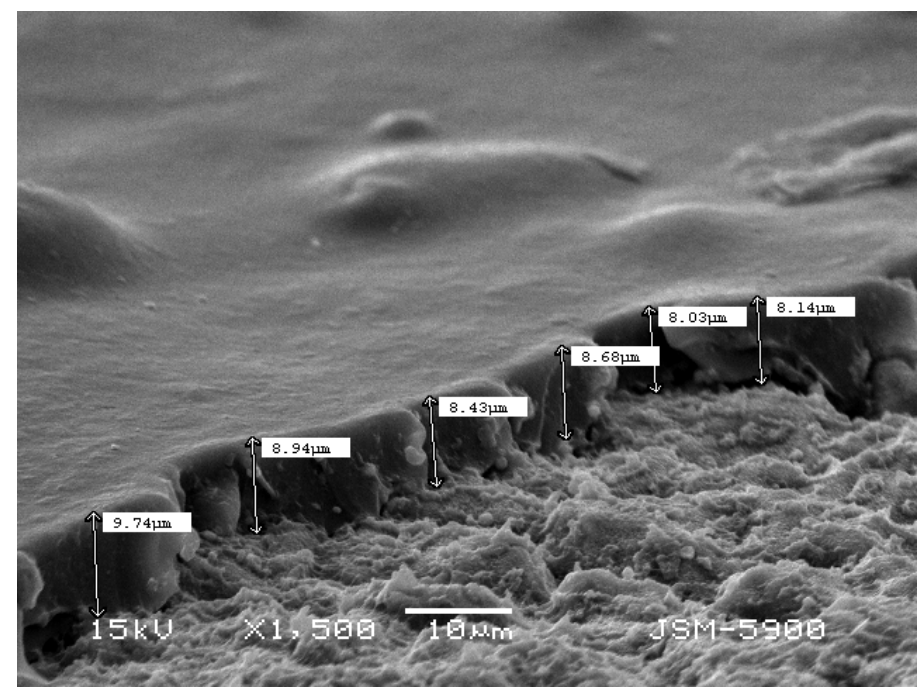

Figure 6. SEM of the cross-section of the composite layer coating on the Ti surfaces, indicating the coating thickness.

The thermal stability of the plain PU coating and the composite coating was investigated using thermogravimetric analysis (TGA), as shown in Figure 6. It appeared that the addition of the Mg particles (Figure 7) improved the thermal stability of the PU as 
compared to the plain PU (Figure 6, S1). Additionally, the TGA thermogram indicated a similar single step degradation pattern for both S2 and S3. The char yield was higher for S3, which was due to the presence of the inorganic component of HAp. The glass transition temperature for the $\mathrm{S} 3$ group, at $50{ }^{\circ} \mathrm{C}$, was marginally higher than that of the S2 group, potentially due to greater secondary interactions and the presence of an additional metal salt. This increase can reasonably be attributed to the coordinated interaction between oxygen and metals/metal ions. The melting point, around $167^{\circ} \mathrm{C}$, appeared to be influenced by the diol component or due to an ordered urea hydrogen bond formation. This may occur due to formation of amine in the presence of residual water/moisture. Finally, the peak around $320^{\circ} \mathrm{C}$ indicated degradation. The improvement in degradation temperature in the composite groups is due to the excellent thermal stability of the $\mathrm{Mg}$ microparticles capsulated within the PU polymer matrix. In addition, the differential scanning calorimetry (DSC) scans (Figure 7) illustrate a slight shifting of the endothermic peaks and heating enthalpies of the coating groups, which is correlated with the melting of PU hard segments [48]. This might suggest typical interactions between the crystalline regions of $\mathrm{PU}$ and the $\mathrm{Mg}$ particles that enhance the stabilization of the dynamic thermal properties of the composite films.

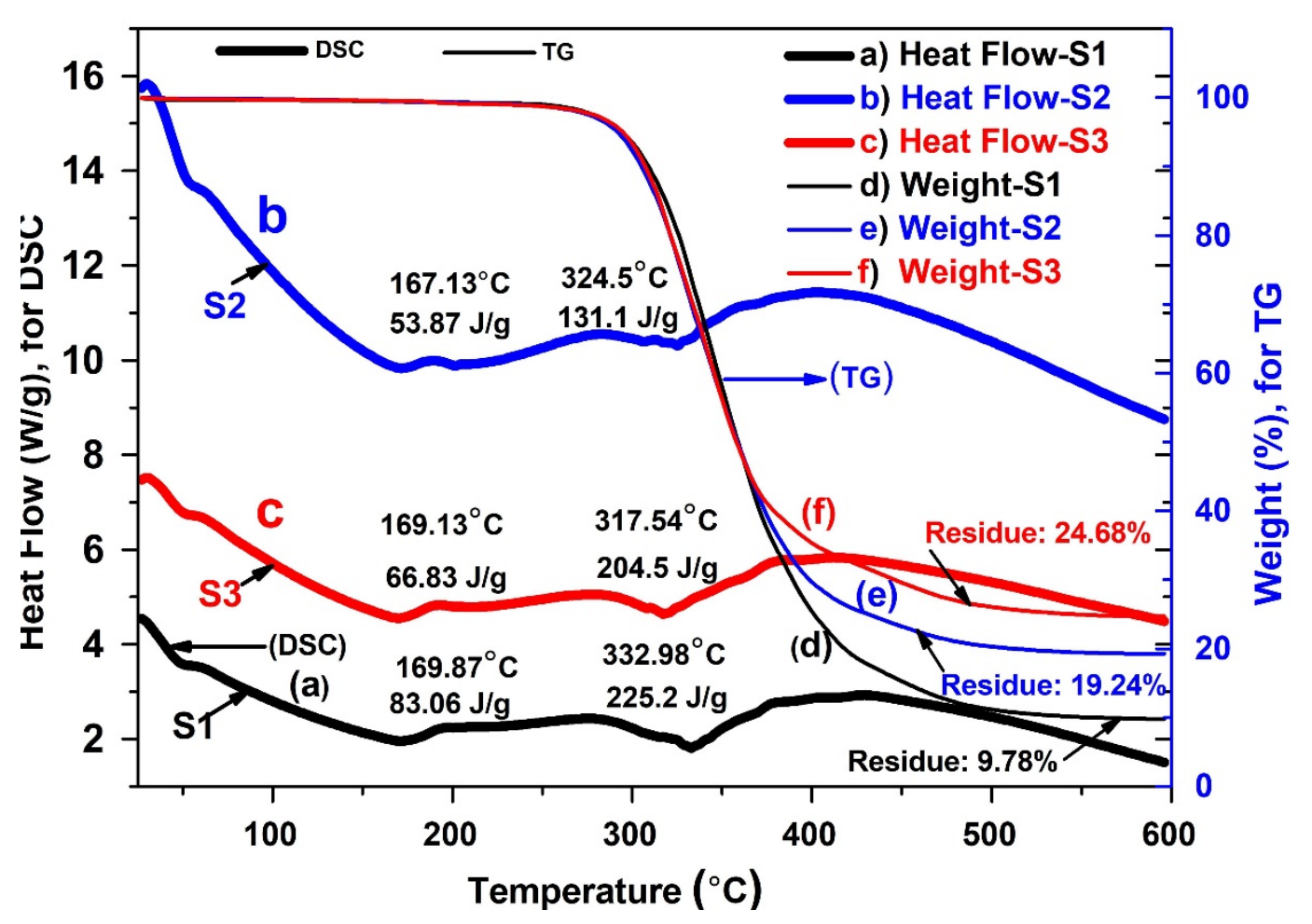

Figure 7. Simultaneous thermogravimetric analysis/differential scanning calorimetry (TGA/DSC) of the three experimental groups comprising plain: $(\mathbf{a}-\mathbf{c})$ heat flow and $(\mathbf{d}-\mathbf{f})$ residual weight of plain and composite layers coated on Ti substrates.

It has been widely reported that coatings can easily delaminate due to a weak adhesion strength, significantly affecting the performance and stability of such coated biomedical devices [49]. In medical device development, adhesion stability between the metal substrate and coating is, therefore, vital to the successful use of implant. The degree of adhesion between the polymer layer and Ti substrate depends intimately on the stability and subsequently longevity of coatings. In the present study, the crosscut (known as tape) adhesion test was conducted to investigate the samples' coating adhesion quality. Table 2 demonstrates the mean of the adhesion performance measurements. Interestingly, as expected, the S2 and S3 groups showed superior adhesion performance (5B, Table 2). It is assumed that the increased surface hydrophilicity (wettability) and the morphological changes caused 
by the alkali treatment improved the interfacial strength between the PU molecules and the treated Ti substrates.

Table 2. Cross-cult adhesion test results of Mg particles/PU and HAp-Mg particles/PU composite coatings formed on alkali-treated Ti (assessed by ASTM (D3359, 2010), a standard protocol).

\begin{tabular}{|c|c|c|c|}
\hline Samples & $\begin{array}{l}\text { Rating of Extent of Adhesion as per } \\
\text { ASTM (D3359, 2010) }\end{array}$ & Percent Area Removed * & $\begin{array}{c}\text { Surface Appearance after Adhesion } \\
\text { Testing }\end{array}$ \\
\hline S2 & $5 \mathrm{~B}$ & $0 \%$ (none) & \\
\hline S3 & $5 \mathrm{~B}$ & $0 \%$ (none) & \\
\hline
\end{tabular}

* Percent area removed was determined based on the classification of adhesion test results of D3359 ASTM standard for measuring adhesion by tape test, according to the following criteria: $5 \mathrm{~B}$ : The edges of the cuts are completely smooth; none of the squares of the lattice are detached.

The degree of surface roughness and charge (wettability) directly influence coating adhesion, with increased surface polarity and roughness resulting in increased reactivity between the substrate and coating. For example, we observed that very fine needle-like hairs were produced on the alkali-treated Ti (inset of Figure 1a). The high surface area of these features appeared to directly improve the adhesion of the deposited PU film [10]. The incorporation of HAp NPs and Mg microparticles into the PU film did not show negative effects on the adhesion performance of the deposited composite film, but instead also improved the adhesion strength.

It is well-known that the adhesion properties between a polymer coating and a metallic surface involves either physical or chemical bonding. In this case, chemical bonding involves a chemical interaction between the deposited PU molecules and species on the alkali-treated Ti surface. Indeed, the surface polarity of the $\mathrm{Na}_{2} \mathrm{TiO}_{3}$ gel layer formed on the $\mathrm{Ti}$ is higher than the untreated Ti surfaces, where the surface comprises an inert amorphous titanium dioxide film. The conversion of the $\mathrm{Na}_{2} \mathrm{TiO}_{3}$ gel layer to titanium-hydroxide (Ti$\mathrm{OH}$ ) after contact with an aqueous environment (such as water vapor) has been reported in our previous work [39], showing that this type of reaction is thermodynamically reasonable. The presence of $\mathrm{OH}$ on a treated Ti substrate may confer interesting properties to the Ti surface. For instance, the alkali-treated Ti surface may conduct as a base when in contact with a PU film. It is therefore suggested that the PU film, which has an acidic group, might strongly interact with the $\mathrm{Na}_{2} \mathrm{TiO}_{3}$ gel layer. These properties make this treatment a very attractive method to enhance the performance of polymer coatings. In fact, this kind of interaction may directly enhance the adhesion strength, as it has been illustrated that electrostatic force develops at the interface between materials that possess different electronic band structures [50]. Thus, the adhesion strength/bonding is strong in the case of the deposition of PU film on the active treated Ti surface.

This phenomenon can be discussed in light of the large number of free ends on the chain of PU, as it has been well discussed in our previous report as well [4], which provide a large number of free carboxyl groups for electrostatic interactions with the alkali-treated titanium surface, as shown in Figure 2. To support our hypothesis, Fouriertransform infrared spectroscopy (FTIR) analyses were used to investigate the molecular level interaction between the film coatings and substrates, as shown in Figure 8. $\mathrm{A} \mathrm{PO}_{4}{ }^{3-}$ 
peak $\left(566 \mathrm{~cm}^{-1}\right)$ was present in the $\mathrm{S} 3$ group, similar to the one present in HAp. As is the case with biological HAp, peaks for carbonate $\left(1411\right.$ and $\left.1136 \mathrm{~cm}^{-1}\right)$ were also present in the S3 group sample. The wide peak around $3361 \mathrm{~cm}^{-1}$ for the S1 and S2 groups were due to the presence of both hydrogen bonds and a free- $\mathrm{NH}$ functional group. After the addition of HAp, there was an increase in absorption due to the H-bonded -NH. The peak around $3500 \mathrm{~cm}^{-1}$ indicated the presence of $-\mathrm{OH}$ groups, which remained broad due to hydrogen bonding. The peak around $2927 \mathrm{~cm}^{-1}$ indicated $-\mathrm{CH}$ stretching. The sharp peak around $1136 \mathrm{~cm}^{-1}$ indicated the presence of the free $-\mathrm{C}=\mathrm{O}$ group of $\mathrm{S} 0$, which reduced upon the addition of $\mathrm{Mg}(\mathrm{S} 1 \mathrm{Mg})$. When HAp was added, the peak again increased, indicating a shifting of interaction from $\mathrm{Mg}$ (with $-\mathrm{C}=\mathrm{O}$ ), to $\mathrm{Mg}$ with HAp. The peak around $1100 \mathrm{~cm}^{-1}$ indicated the presence of an ether linkage, while a peak for $\mathrm{Mg}(\mathrm{OH})_{2}$ was also present at $510 \mathrm{~cm}^{-1}$ in both S2 and S3 group samples [51].

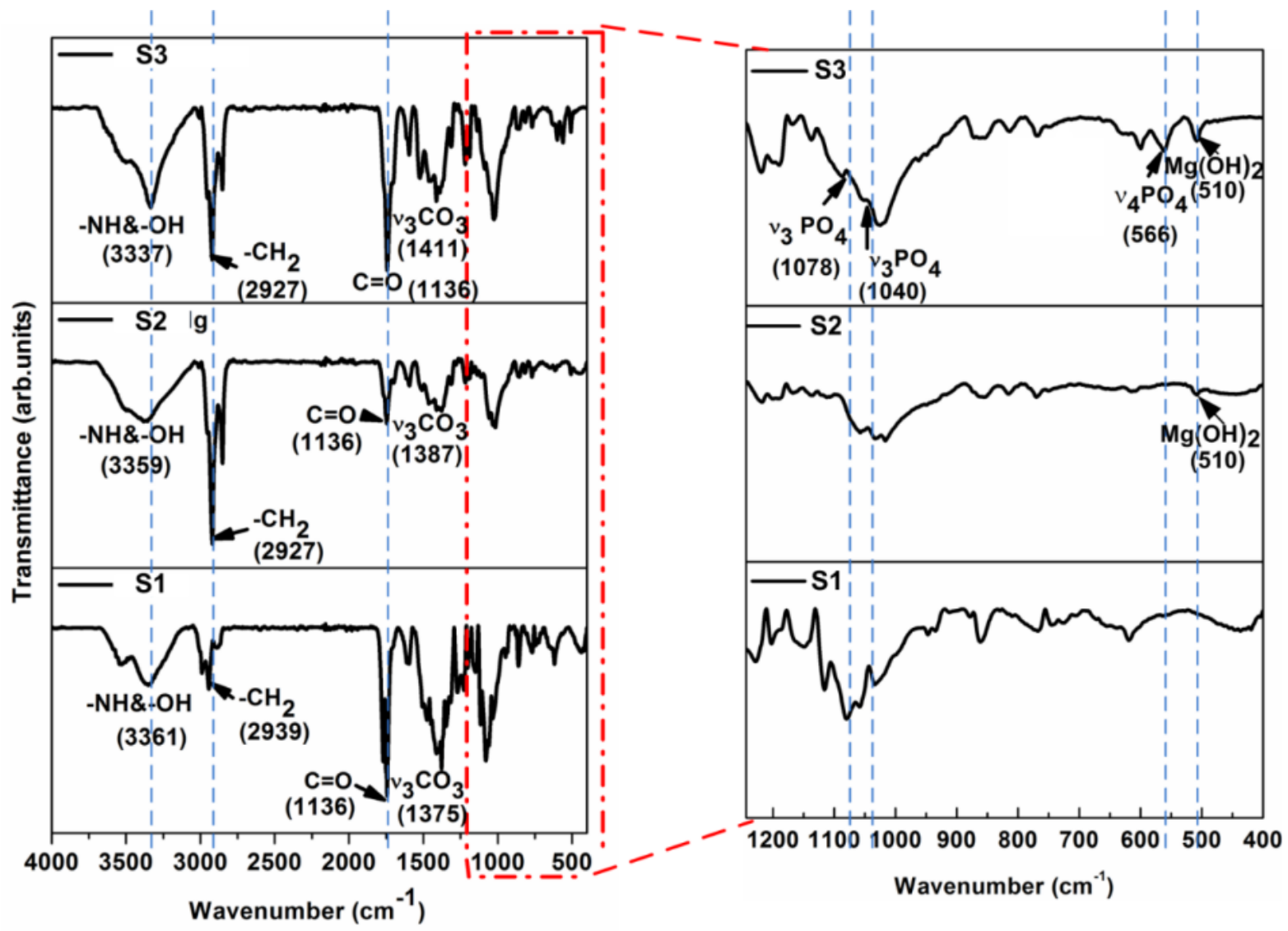

Figure 8. FT-IR spectra in transmission mode of a typical sample surface, comprising Ti coated with PU with and without $\mathrm{Mg}$ and HAp particles, after a $5 \mathrm{M} \mathrm{NaOH}$ chemical treatment at $60^{\circ} \mathrm{C}$ for $24 \mathrm{~h}$ of the Ti samples.

The evaluation of cell/biomaterial interactions through the assessment of in vitro cytotoxicity test is one of the most fundamental initial tests for developed biomaterials [52]. Furthermore, the successful attachment of cells is an important part of this process and can strongly affect the subsequent cellular and tissue response. Figure 9 shows the cell morphology after three and five days of cell culture. The obtained images show the differential interaction of the cells with the different surfaces (some focusing issues arose from partial film detachment during the fixing, staining and dehydration processes). 

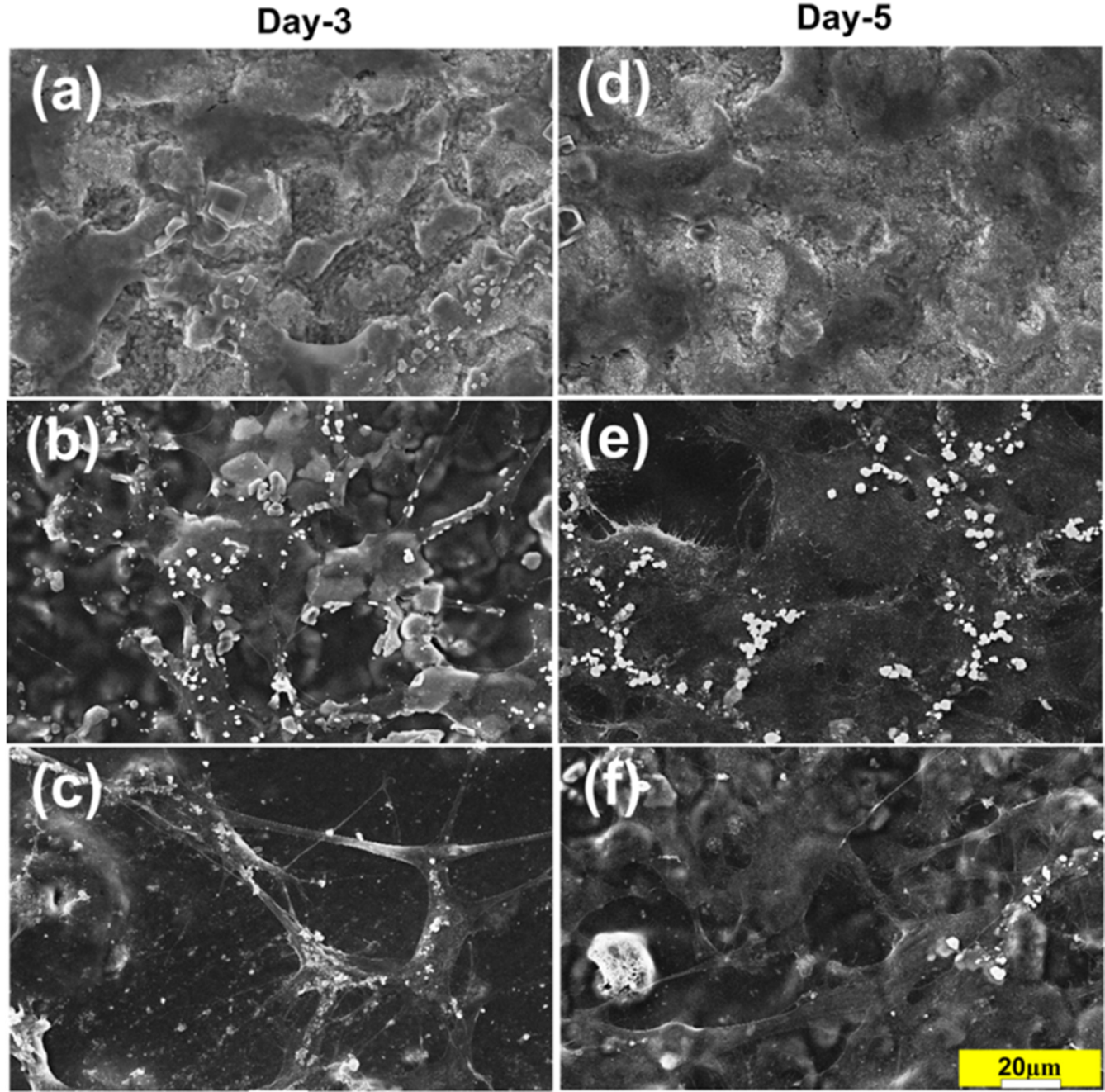

Figure 9. SEM images of MC3T3 osteoblastic cells lines cultured for three and five days on the treated and treated Ti surfaces of S0 (a,d), S2 (b,e) and S3 group (c,f). Scale bar $20 \mu \mathrm{m}$.

For the S0 group, only a few, after three days of culture and after five days poorly spread cells were observed, no additional changes in cell morphology were noticed (Figure 9). The coating remained intact throughout the culture period. In the S2 and S3 groups, there were similarly no defects, detachments, or other degradations in the coating after 5 days of culture (Figure $9 \mathrm{~b}-\mathrm{f}$ ), and a clear cellular spreading was observed, particularly in group S3. These results suggest that the S3 group had the most cytocompatible characteristics among the tested groups (Figure 9e,f). The $\mathrm{S} 0$ group possessed a higher surface roughness $(1.110 \pm 0.015 \mu \mathrm{m})$ than the $\mathrm{S} 2$ group $(0.611 \pm 0.020 \mu \mathrm{m})$, which would typically indicate that it should have superior performance in terms of cell migration, spreading. However, the S2 group surface also possessed a lower stiffness than the S1 surface, and indeed previous studies [53] showed that cell migration and focal adhesion are regulated by substrate flexibility. A study by Pelham and colleagues [54] found that cell spreading/migration could be guided by surface topography and physical interactions between the cell and the materials' substrate. Their study concluded that changes in tissue rigidity and flexibility could play an important role in controlling cell spreading and migration. Additionally, cell spreading, and focal adhesions were affected by a change in mechanical properties of the extracellular matrix (ECM), which influenced cytoskeletal stiffness in vitro [52]. Ti-based implants possess a high stiffness that is responsible for the commonly problematic stress shielding phenomenon (i.e., there is a poor integration of the Ti implant with surrounding host tissues). Overall, it appears that the PU coating of 
alkali-treated Ti surfaces may regulate the adhesion and interactions of osteoblastic cells and the substrate.

Results of the MTT-assay confirmed that cell proliferation occurred over the 3 and 5 days of cell culture (Figure 10a). On day 3, it was observed that the S0 samples showed less cell proliferation than the S2 and S3 samples. After $5 \mathrm{~d}$ of culture, all groups showed a significant increase, and maintained over $80 \%$ viability. It has previously been reported that the formation of sodium titanate on the surface of Ti implants that are implanted in the body may have a harmful effect on cellular response because of the excessive release of sodium ions and the formation of narrow pore spaces [55]. We also observed that the $\mathrm{Na}^{+}$ ions released from the alkali-treated Ti surfaces had a negative effect on cell proliferation, despite the surface having an increased hydrophilicity [2]. However, the biocompatibility of the material was improved after coating, particularly with the S3 group samples, which performed the best of all of the groups.
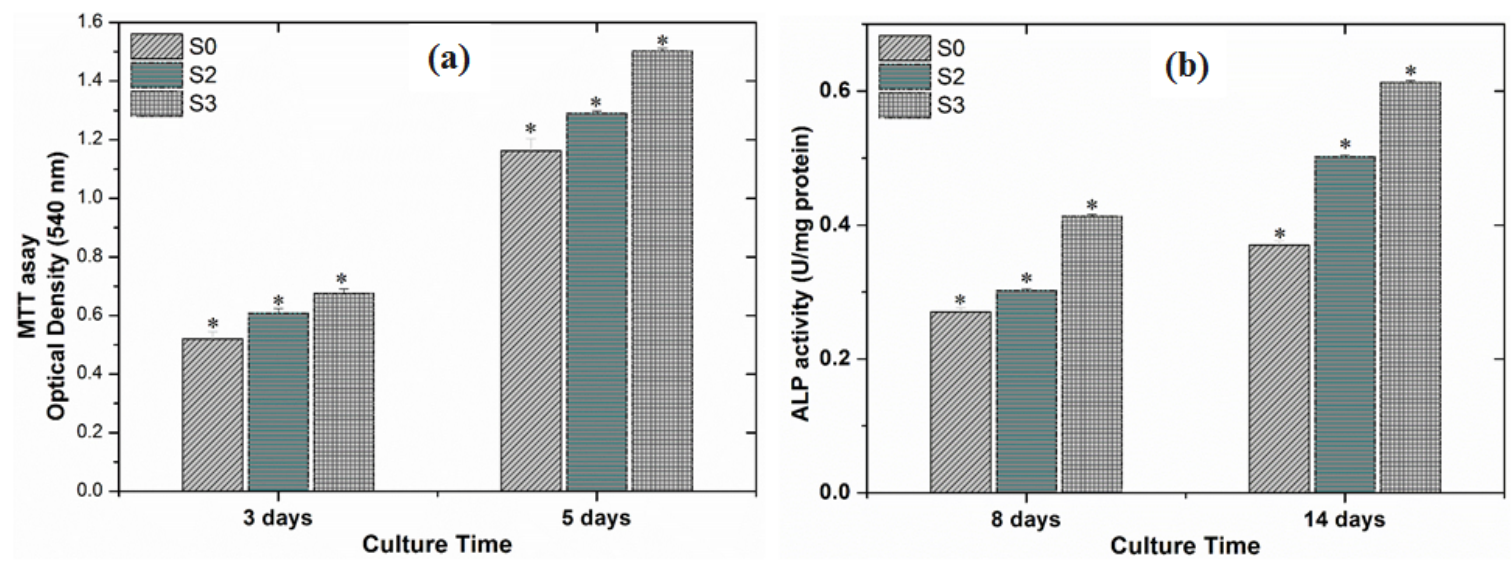

Figure 10. (a) Cell proliferation assay after 3 and $5 \mathrm{~d}$ of culture and (b) Alkaline phosphate activity (ALP) (U/mg protein) after 8 and $14 \mathrm{~d}$ of culture; cells were seeded on coated alkaline treated Ti samples $\left(\mathrm{n}=3,{ }^{*}\right.$ indicates $\left.p \leq 0.05\right)$.

Alkaline phosphate (ALP) is an early marker of osteoblast differentiation. We observed a clear increase in ALP activity after 8 and $14 \mathrm{~d}$ of culture, with ALP activity showing a significant increase in group S3 by day 14 (Figure 10b). Overall, the best outcomes in terms of cell proliferation and differentiation were observed in group S3. This observation indicates that there is a positive correlation between $\mathrm{Mg}^{2+}$ ion release into the media and an increase in osteogenic response.

The effect of $\mathrm{Mg}^{2+}$ ions on bone growth and bone formation was recently investigated [56]. The studies of the role of $\mathrm{Mg}^{2+}$ ions in accelerating bone formation have showed that the ions not only enhance bone adhesion and bone healing but also aid in the regulation and acceleration formation of bone marrow cells through the enhancement of BMP-receptor recognition, Smad signaling pathways, and/or the upregulation of neuronal calcitonin gene-related polypeptide (CGRP) [57,58]. The stimulation of bone formation by $\mathrm{Mg}^{2+}$ ions has been widely reported including ours, primarily through enhancing the activity of osteoblast, including adhesion/attachment, growth, and differentiation of these cells [30]. $\mathrm{Mg}^{2+}$ ions are actively involved in the process minerals formation to control bone formation and resorption [23]. Accordingly, the hypothesis that the S3 samples would increase MC3T3-E1 proliferation and differentiation compared with S0 samples, is accepted. Finally, it appears that coatings of both plain PU and PU doped with metallic Mg particles in a thin film deposited on a Ti implant are safe and effective in an in vitro cell culture model. Using a HAp/Mg/PU film coating on the Ti implants also further increased the level of osteoblast cell proliferation and differentiation, benefiting from the synergistic effects of both $\mathrm{Mg}$ and HAp. We have planned future work to investigate the microenvironment of the coated implants more comprehensively, and furthermore plan to conduct in vivo 
studies where we evaluate the coating durability, and the osteogenesis, osteoinduction, and osseointegration of these implants.

\section{Conclusions}

In this study, alkali-treated Ti substrates were coated with thin films of PU, PU with $\mathrm{Mg}$ particles, and PU with Mg and hydroxyapatite (HAp) particles using a dip-coating technology. The coatings were stable and did not delaminate from the implant surfaces. The use of dip-coating technology allowed us to create novel composites, introducing biologically compatible metal particles $(\mathrm{Mg})$ and HAp onto alkali-treated $\mathrm{Ti}$ in a short time using a facile process. The morphology of the modified Ti surface interacted very favorably with the HAp NPs, increasing the adhesive strength between the substrate and the coating. Additionally, the surface charge (wettability) of the HAp NPs appeared to improve the interfacial strength by interacting with the sodium titanate gel layer formed on the treated Ti substrates. The HAp/Mg/PU group achieved the most positive effects in terms of enhancing preosteoblast adhesion, proliferation, and differentiation, which can be attributed to the bioactivity and biocompatibility of both the HAp particles and $\mathrm{Mg}^{2+}$ ions released from the metal particles. Overall, our results suggest that $\mathrm{HAp} / \mathrm{Mg} / \mathrm{PU}$ coated alkali-treated Ti is highly suitable as a biodegradable and bioactive orthopedic implant material.

Supplementary Materials: The following are available online at https://www.mdpi.com/article/ 10.3390/nano11051129/s1, Sample preparation, Wet chemical synthesis of HAp, Coating process, Characterization, Adhesion performance, Osteoblast cell response.

Author Contributions: Conceptualization, A.A.-h. and M.A.; methodology, M.A.; software, M.A.; validation, M.A.; original draft preparation, M.A. and A.A.-h.; writing-review and editing, M.K.H., M.B., and S.I.; visualization, S.I.; supervision, A.A.-h. and S.I. All authors have read and agreed to the published version of the manuscript.

Funding: This research received no external funding.

Institutional Review Board Statement: Not applicable.

Informed Consent Statement: Not applicable.

Acknowledgments: The authors acknowledge the facilities, and the scientific and technical assistance, of the Australian Microscopy \& Microanalysis Research Facility at the Centre for Microscopy and Microanalysis, The University of Queensland.

Conflicts of Interest: The authors declare no conflict of interest.

\section{References}

1. Park, K.-D.; Lee, B.-A.; Piao, X.-H.; Lee, K.-K.; Park, S.-W.; Oh, H.-K.; Kim, Y.-J.; Park, H.-J. Effect of magnesium and calcium phosphate coatings on osteoblastic responses to the titanium surface. J. Adv. Prosthodont. 2013, 5, 402-408. [CrossRef]

2. Young Kim, S.; kyoung Kim, Y.; song Park, I.; chun Jin, G.; sung Bae, T.; ho Lee, M. Effect of alkali and heat treatments for bioactivity of $\mathrm{TiO}_{2}$ nanotubes. Appl. Surf. Sci. 2014, 321, 412-419.

3. Roy, P.; Berger, S.; Schmuki, P. TiO 2 nanotubes: Synthesis and applications. Angew. Chem. Int. Ed. 2011, 50, 2904-2939. [CrossRef]

4. Abdal-hay, A.; Agour, M.; Kim, Y.-K.; Lee, M.-H.; Hassan, M.K.; El-Ainin, H.A.; Hamdy, A.S.; Ivanovski, S. Magnesiumparticle/polyurethane composite layer coating on titanium surfaces for orthopedic applications. Eur. Polym. J. 2019, 112, 555-568. [CrossRef]

5. Lim, Y.J.; Oshida, Y.; Andres, C.J.; Barco, M.T. Surface characterizations of variously treated titanium materials. Int. J. Oral Maxillofac. Implants 2001, 16, 333-342. [PubMed]

6. Lopes, M.A.; Monteiro, F.; Santos, J.; Serro, A.; Saramago, B. Hydrophobicity, surface tension, and zeta potential measurements of glass-Reinforced hydroxyapatite composites. J. Biomed. Mater. Res. 1999, 45, 370-375. [CrossRef]

7. Webster, T.J.; Ergun, C.; Doremus, R.H.; Siegel, R.W.; Bizios, R. Specific proteins mediate enhanced osteoblast adhesion on nanophase ceramics. J. Biomed. Mater. Res. 2000, 51, 475-483. [CrossRef]

8. Ferraz, M.; Monteiro, F.; Serro, A.; Saramago, B.; Gibson, I.R.; Santos, J. Effect of chemical composition on hydrophobicity and zeta potential of plasma sprayed $\mathrm{HA} / \mathrm{CaO}-\mathrm{P}_{2} \mathrm{O}_{5}$ glass coatings. Biomaterials 2001, 22, 3105-3112. [CrossRef]

9. Botelho, C.; Lopes, M.; Gibson, I.R.; Best, S.; Santos, J. Structural analysis of Si-substituted hydroxyapatite: Zeta potential and X-ray photoelectron spectroscopy. J. Mater. Sci. Mater. Med. 2002, 13, 1123-1127. [CrossRef] [PubMed] 
10. Abdal-Hay, A.; Hamdy, A.S.; Khalil, K.A.; Lim, J.H. A novel simple one-step air jet spinning approach for deposition of poly (vinyl acetate)/hydroxyapatite composite nanofibers on Ti implants. Mater. Sci. Eng. C 2015, 49, 681-690. [CrossRef]

11. Vlacic-Zischke, J.; Hamlet, S.; Friis, T.; Tonetti, M.; Ivanovski, S. The influence of surface microroughness and hydrophilicity of titanium on the up-regulation of TGF $\beta$ /BMP signalling in osteoblasts. Biomaterials 2011, 32, 665-671. [CrossRef]

12. Abdal-hay, A.; Abbasi, N.; Gwiazda, M.; Hamlet, S.; Ivanovski, S. Novel polycaprolactone/hydroxyapatite nanocomposite fibrous scaffolds by direct melt-electrospinning writing. Eur. Polym. J. 2018, 105, 257-264. [CrossRef]

13. Abdal-hay, A.; Fouad, H.; ALshammari, B.A.; Khalil, K.A. Biosynthesis of bonelike apatite 2D nanoplate structures using fenugreek seed extract. Nanomaterials 2020, 10, 919. [CrossRef]

14. Porter, A.E.; Taak, P.; Hobbs, L.W.; Coathup, M.J.; Blunn, G.W.; Spector, M. Bone bonding to hydroxyapatite and titanium surfaces on femoral stems retrieved from human subjects at autopsy. Biomaterials 2004, 25, 5199-5208. [CrossRef] [PubMed]

15. Khalil, K.A.; Kim, S.W.; Dharmaraj, N.; Kim, K.W.; Kim, H.Y. Novel mechanism to improve toughness of the hydroxyapatite bioceramics using high-frequency induction heat sintering. J. Mater. Process. Technol. 2007, 187, 417-420. [CrossRef]

16. Barakat, N.A.; Khalil, K.; Sheikh, F.A.; Omran, A.; Gaihre, B.; Khil, S.M.; Kim, H.Y. Physiochemical characterizations of hydroxyapatite extracted from bovine bones by three different methods: Extraction of biologically desirable HAp. Mater. Sci. Eng. C 2008, 28, 1381-1387. [CrossRef]

17. Lin, D.-Y.; Wang, X.-X. Preparation of hydroxyapatite coating on smooth implant surface by electrodeposition. Ceram. Int. 2011, 37, 403-406. [CrossRef]

18. Szymura-Oleksiak, J.; Ślósarczyk, A.; Cios, A.; Mycek, B.; Paszkiewicz, Z.; Szklarczyk, S.; Stankiewicz, D. The kinetics of pentoxifylline release in vivo from drug-loaded hydroxyapatite implants. Ceram. Int. 2001, 27, 767-772. [CrossRef]

19. Chen, B.; Zhang, T.; Zhang, J.; Lin, Q.; Jiang, D. Microstructure and mechanical properties of hydroxyapatite obtained by gel-casting process. Ceram. Int. 2008, 34, 359-364. [CrossRef]

20. Abdal-hay, A.; Barakat, N.A.; Lim, J.K. Hydroxyapatite-doped poly (lactic acid) porous film coating for enhanced bioactivity and corrosion behavior of AZ31 Mg alloy for orthopedic applications. Ceram. Int. 2013, 39, 183-195. [CrossRef]

21. Wang, C.; Wang, M. Electrochemical impedance spectroscopy study of the nucleation and growth of apatite on chemically treated pure titanium. Mater. Lett. 2002, 54, 30-36. [CrossRef]

22. Xu, L.; Pan, F.; Yu, G.; Yang, L.; Zhang, E.; Yang, K. In vitro and in vivo evaluation of the surface bioactivity of a calcium phosphate coated magnesium alloy. Biomaterials 2009, 30, 1512-1523. [CrossRef] [PubMed]

23. Ibasco, S.; Tamimi, F.; Meszaros, R.; Le Nihouannen, D.; Vengallatore, S.; Harvey, E.; Barralet, J.E. Magnesium-sputtered titanium for the formation of bioactive coatings. Acta Biomater. 2009, 5, 2338-2347. [CrossRef] [PubMed]

24. Huynh, V.; Ngo, N.K.; Golden, T.D. Surface activation and pretreatments for biocompatible metals and alloys used in biomedical applications. Int. J. Biomater. 2019, 2019, 3806504. [CrossRef] [PubMed]

25. Xuhui, Z.; Lingfang, Y.; Yu, Z.; Xiong, J. Hydroxyapatite coatings on titanium prepared by electrodeposition in a modified simulated body fluid. Chin. J. Chem. Eng. 2009, 17, 667-671.

26. Rath, P.C.; Besra, L.; Singh, B.P.; Bhattacharjee, S. Titania/hydroxyapatite bi-layer coating on Ti metal by electrophoretic deposition: Characterization and corrosion studies. Ceram. Int. 2012, 38, 3209-3216. [CrossRef]

27. Cifuentes, S.C.; Gavilán, R.; Lieblich, M.; Benavente, R.; González-Carrasco, J.L. In vitro degradation of biodegradable polylactic acid/magnesium composites: Relevance of Mg particle shape. Acta Biomater. 2016, 32, 348-357. [CrossRef]

28. Shuai, C.; Li, Y.; Feng, P.; Guo, W.; Yang, W.; Peng, S. Positive feedback effects of Mg on the hydrolysis of poly-l-lactic acid (PLLA): Promoted degradation of PLLA scaffolds. Polym. Test. 2018, 68, 27-33. [CrossRef]

29. Zimmermann, T.; Ferrandez-Montero, A.; Lieblich, M.; Ferrari, B.; González-Carrasco, J.L.; Müller, W.-D.; Schwitalla, A.D. In vitro degradation of a biodegradable polylactic acid/magnesium composite as potential bone augmentation material in the presence of titanium and PEEK dental implants. Dent. Mater. 2018, 34, 1492-1500. [CrossRef] [PubMed]

30. Abdal-hay, A.; Dewidar, M.; Lim, J.; Lim, J.K. Enhanced biocorrosion resistance of surface modified magnesium alloys using inorganic/organic composite layer for biomedical applications. Ceram. Int. 2014, 40, 2237-2247. [CrossRef]

31. Barrere, F.; Van Der Valk, C.; Meijer, G.; Dalmeijer, R.; De Groot, K.; Layrolle, P. Osteointegration of biomimetic apatite coating applied onto dense and porous metal implants in femurs of goats. J. Biomed. Mater. Res. Part. B Appl. Biomater. 2003, 67, 655-665. [CrossRef]

32. Guelcher, S.A. Biodegradable polyurethanes: Synthesis and applications in regenerative medicine. Tissue Eng. Part. B Rev. 2008, 14, 3-17. [CrossRef] [PubMed]

33. Wang, P.; Li, C.; Gong, H.; Jiang, X.; Wang, H.; Li, K. Effects of synthesis conditions on the morphology of hydroxyapatite nanoparticles produced by wet chemical process. Powder Technol. 2010, 2032, 315-321. [CrossRef]

34. Song, G.; Song, S. A possible biodegradable magnesium implant material. Adv. Eng. Mater. 2007, 9, 298-302. [CrossRef]

35. Kokubo, T.; Kim, H.-M.; Kawashita, M. Novel bioactive materials with different mechanical properties. Biomaterials 2003, 24, 2161-2175. [CrossRef]

36. Lu, X.; Wang, Y.-B.; Liu, Y.-R.; Wang, J.-X.; Qu, S.-X.; Feng, B.; Weng, J. Preparation of HA/chitosan composite coatings on alkali-treated titanium surfaces through sol-gel techniques. Mater. Lett. 2007, 61, 3970-3973. [CrossRef]

37. Cui, W.; Jin, L.; Zhou, L. Surface characteristics and electrochemical corrosion behavior of a pre-anodized microarc oxidation coating on titanium alloy. Mater. Sci. Eng. C 2013, 33, 3775-3779. [CrossRef] 
38. Xie, Y.; Ao, H.; Xin, S.; Zheng, X.; Ding, C. Enhanced cellular responses to titanium coating with hierarchical hybrid structure. Mater. Sci. Eng. C 2014, 38, 272-277. [CrossRef]

39. Abdal-hay, A.; Gulati, K.; Fernandez-Medina, T.; Qian, M.; Ivanovski, S. In situ hydrothermal transformation of titanium surface into lithium-doped continuous nanowire network towards augmented bioactivity. Appl. Surf. Sci. 2020, 505, 144604. [CrossRef]

40. Abdal-hay, A.; Amna, T.; Lim, J.K. Biocorrosion and osteoconductivity of PCL/nHAp composite porous film-based coating of magnesium alloy. Solid State Sci. 2012, 18, 131-140. [CrossRef]

41. Da Conceicao, T.; Scharnagl, N.; Blawert, C.; Dietzel, W.; Kainer, K. Surface modification of magnesium alloy AZ31 by hydrofluoric acid treatment and its effect on the corrosion behaviour. Thin Solid Film. 2010, 518, 5209-5218. [CrossRef]

42. da Conceição, T.F. Corrosion Protection of Magnesium AZ31 Alloy Sheets by Polymer Coatings. Ph.D. Thesis, Technische Universität, Berlin, Germany, 2011.

43. Siau, S.; Vervaet, A.; Degrande, S.; Schacht, E.; Van Calster, A. Dip coating of dielectric and solder mask epoxy polymer layers for build-up purposes. Appl. Surf. Sci. 2005, 245, 353-368. [CrossRef]

44. Fang, H.-W.; Li, K.-Y.; Su, T.-L.; Yang, T.C.-K.; Chang, J.-S.; Lin, P.-L.; Chang, W.-C. Dip coating assisted polylactic acid deposition on steel surface: Film thickness affected by drag force and gravity. Mater. Lett. 2008, 62, 3739-3741. [CrossRef]

45. Yimsiri, P.; Mackley, M.R. Spin and dip coating of light-emitting polymer solutions: Matching experiment with modelling. Chem. Eng. Sci. 2006, 61, 3496-3505. [CrossRef]

46. Shukla, A.; Balasubramaniam, R. Effect of surface treatment on electrochemical behavior of CP Ti, Ti-6Al-4V and Ti-13Nb-13Zr alloys in simulated human body fluid. Corros. Sci. 2006, 48, 1696-1720. [CrossRef]

47. Xue, W.; Liu, X.; Zheng, X.; Ding, C. In vivo evaluation of plasma-sprayed titanium coating after alkali modification. Biomaterials 2005, 26, 3029-3037. [CrossRef] [PubMed]

48. Abdal-hay, A.; Bartnikowski, M.; Hamlet, S.; Ivanovski, S. Electrospun biphasic tubular scaffold with enhanced mechanical properties for vascular tissue engineering. Mater. Sci. Eng. C 2018, 82, 10-18. [CrossRef]

49. Burke, M.; Clarke, B.; Rochev, Y.; Gorelov, A.; Carroll, W. Estimation of the strength of adhesion between a thermoresponsive polymer coating and nitinol wire. J. Mater. Sci. Mater. Med. 2008, 19, 1971-1979. [CrossRef] [PubMed]

50. Catauro, M.; Bollino, F.; Papale, F.; Giovanardi, R.; Veronesi, P. Corrosion behavior and mechanical properties of bioactive sol-gel coatings on titanium implants. Mater. Sci. Eng. C 2014, 43, 375-382. [CrossRef]

51. Feng, J.; Chen, Y.; Liu, X.; Liu, T.; Zou, L.; Wang, Y.; Ren, Y.; Fan, Z.; Lv, Y.; Zhang, M. In-situ hydrothermal crystallization $\mathrm{Mg}(\mathrm{OH})_{2}$ films on magnesium alloy AZ91 and their corrosion resistance properties. Mater. Chem. Phys. 2013, 143, 322-329. [CrossRef]

52. Halliday, N.L.; Tomasek, J.J. Mechanical properties of the extracellular matrix influence fibronectin fibril assembly in vitro. Exp. Cell Res. 1995, 217, 109-117. [CrossRef]

53. Pelham, R.J.; Wang, Y.-L. Cell locomotion and focal adhesions are regulated by substrate flexibility. Proc. Natl. Acad. Sci. USA 1997, 94, 13661-13665. [CrossRef]

54. Lo, C.-M.; Wang, H.-B.; Dembo, M.; Wang, Y.-L. Cell movement is guided by the rigidity of the substrate. Biophys. J. 2000, 79, 144-152. [CrossRef]

55. Pattanayak, D.K.; Yamaguchi, S.; Matsushita, T.; Kokubo, T. Nanostructured positively charged bioactive $\mathrm{TiO}_{2}$ layer formed on Ti metal by $\mathrm{NaOH}$, acid and heat treatments. J. Mater. Sci. Mater. Med. 2011, 22, 1803-1812. [CrossRef]

56. Zhang, Y.; Xu, J.; Ruan, Y.C.; Yu, M.K.; O'Laughlin, M.; Wise, H.; Chen, D.; Tian, L.; Shi, D.; Wang, J. Implant-derived magnesium induces local neuronal production of CGRP to improve bone-fracture healing in rats. Nat. Med. 2016, 22, 1160. [CrossRef]

57. Brown, A.; Zaky, S.; Ray, H.; Sfeir, C. Porous magnesium/PLGA composite scaffolds for enhanced bone regeneration following tooth extraction. Acta Biomater. 2015, 11, 543-553. [CrossRef] [PubMed]

58. Alvarez-Lopez, M.; Pereda, M.D.; del Valle, J.A.; Fernandez-Lorenzo, M.; Garcia-Alonso, M.C.; Ruano, O.A.; Escudero, M.L. Corrosion behaviour of AZ31 magnesium alloy with different grain sizes in simulated biological fluids. Acta Biomater. 2010, 6, 1763-1771. [CrossRef] [PubMed] 